\title{
Cognitive Processes and Personality Traits in Virtual Reality Educational and Training
}

\author{
Vladimir V. Selivanov ${ }^{a^{*}}$, Lyudmila N. Selivanova ${ }^{b}$, Nigina S. Babieva ${ }^{c}$ \\ ${ }^{a}$ Moscow State University of Psychology and Education, Moscow, Russia \\ b Smolensk State University, Smolensk, Russia \\ ' Sechenov First Moscow State Medical University, Moscow, Russia \\ *Corresponding author. E-mail: vvsel@list.ru
}

Background. Virtual reality (VR) is designed to provide a person's contact with informational reality. VR technology is an effective tool for solving a whole class of economic problems, when it is cheaper and safer to carry out preliminary tests in virtual technology than in reality. In psychology, sociology, and pedagogy, virtual reality technologies provide the ability to model complex social objects (not just stimulis, irritants).

Objective. In our study we explored the influence which virtual reality has on cognitive processes and personality characteristics. The study analyzes the influence of educational VR programs on cognitive processes and a number of personal characteristics.

Results. Laboratory experiments show that short-term work in the educational VR (created as a study of complex topics in Biology and Geometry) positively affects cognition and thinking. VR-programs improve traditional parameters of figurative short-term memory, observation and generalization. Students in the control group had significantly lower values. In fact, the technologies designed in the VR do not affect the basic personal structures, rather they only influence the functional personality characteristics.

Conclusion. Short-term work in the educational VR positively affects the development of knowledge, thinking, memory, observation and attention span, as well as increasing field independence. The work of a person with training and educational programs in the virtual reality does not cause any alteration of the basic personal traits. Our result justifies the use of VR for educational purposes and professional training.

Keywords: Virtual reality (VR); changes of cognitive processes; personality; thinking 


\section{Introduction}

Currently, whenever the efficiency of science and technology plays a role in the balanced development of a country (Huan, 2017), virtual reality technology is being used extensively. VR technology is effective for the resolution of current tasks in social research from the perspective of the postnonclassical approach (Zinchenko et al., 2015). The influence of virtual reality (VR) on cognitive processes and personality traits has become a reality for modern psychological and pedagogical science, and social work. The research we present here is generally aimed at elucidating and describing the basic changes which occur in cognitive processes (primarily thinking and memory) under the influence of virtual reality.

Virtual reality is defined as high-tech products characterized by three-dimensional images of objects, animations, and interactivity functions, which are immersive by their nature. The authors share K. Murray's philosophical interpretation of virtual reality, which looks similar to the world of ideas described by Plato. K. Murray defined those ideas as a combination of pure entities, i.e., extremely generalized, invariant properties of objects (Murray, 2000). The real, visible human world is the shadow of the world of ideas. Virtual objects have slightly different properties than natural things. For example, a VR-house cannot be ruined, burnt, or flooded unless the researcher programmed in these properties.

The present research interprets the essence of the virtual reality in a traditional cybernetic sense, which in turn determines its following basic characteristics: 1) creation of digital three-dimensional images imitating real objects; 2) animation opportunities; 3) network real-time data processing; and 4) the presence effect (the co-experience illusion a person might have in the artificial digital reality while interacting with objects or subjects) (Lombard \& Ditton, 1997).

On the whole, virtual reality can be treated as a technology of man-machine interaction, which enables the users to immerse themselves in the 3-D interactive information environment. Virtual reality technologies are actively used in the study of visual illusions (Menshikova, 2013a, Menshikova, 2013b); parameters of the vestibular apparatus (Menshikova et al., 2017); research on the presence effect (Velichkovsky et al., 2016); and social research, including investigation of ethnic attitudes (Menshikova et al., 2018). Such research is carried out at the Faculty of Psychology of Moscow State University, including using the virtual reality room (CAVE). Virtual reality technologies are widely used in psychotherapy, counseling, and psycho-correction in Europe and the United States.

In 2008 the International Association of Cyber Therapy and Rehabilitation (founded in Brussels, Belgium), published the Cyber Therapy \& Rehabilitation journal (Voiskynsky, 2010, p. 203). The research they published proved virtual therapy to be efficient in helping people get over or reduce fear, anxiety, and phobias (Hodges et al., 2001; Riva, 2005; Rothbaum et al., 1990; Seliskya et al., 2004; Selivanov, 2015; 2016; Slater et al., 2016), especially with the use of an avatar (an avatar is defined as a VR object controlled by a person who identifies him or herself with it) (Meyerbroeker et al., 2008; Riva, 2008). Combined cognitive-motor rehabilitation in virtual reality also leads to more successful elimination of cognitive and motor deficits after a stroke (Faria et al., 2018). 
In our opinion, VR technologies can be effective in training individuals on how to overcome many negative socially determined experiences and emotions such as microaggressions, which are subtle verbal and non-verbal slights based on group membership, and are ubiquitous in the lives of racial minorities (Byrd, 2018). This is done by creating various systems of learning in the network for use by adults (Norris et al. 2018).

\section{Methods}

\section{Technology}

This research was based on five VR educational programs in Biology and Geometry, which were created under the guidance of experts ("Inheritance of genes," "Protein synthesis," etc.) using the "Unity" multiplatform tool for three-dimensional images. The programs were designed for high school students. The software provides great animation opportunities; on average, program viewing takes 8-15 min. (Figs. 1 and 2).

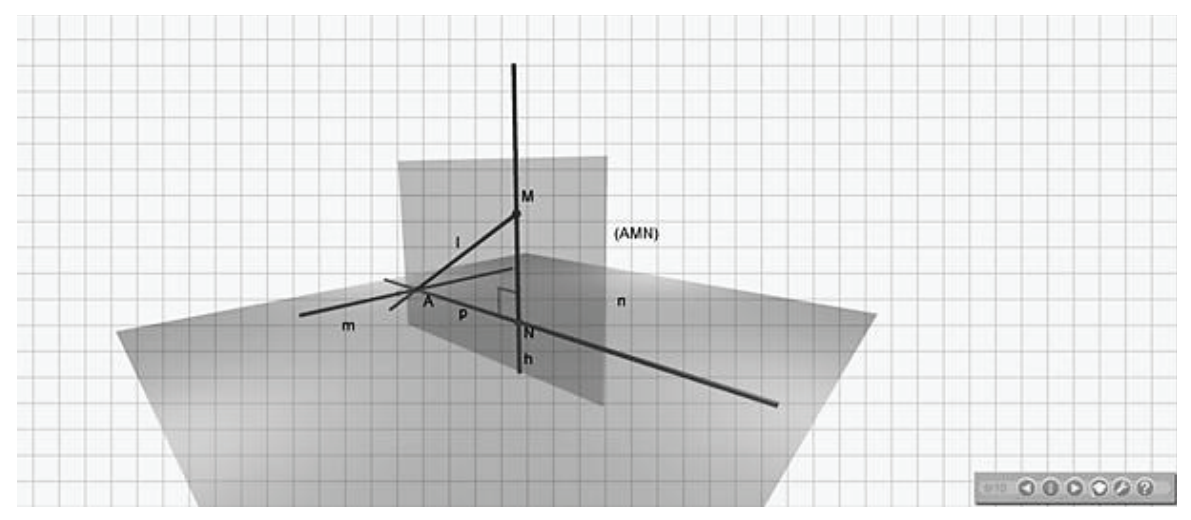

Figure 1. A screenshot from the program "Three perpendiculars theorem" with animated planes and lines, and audio explanation

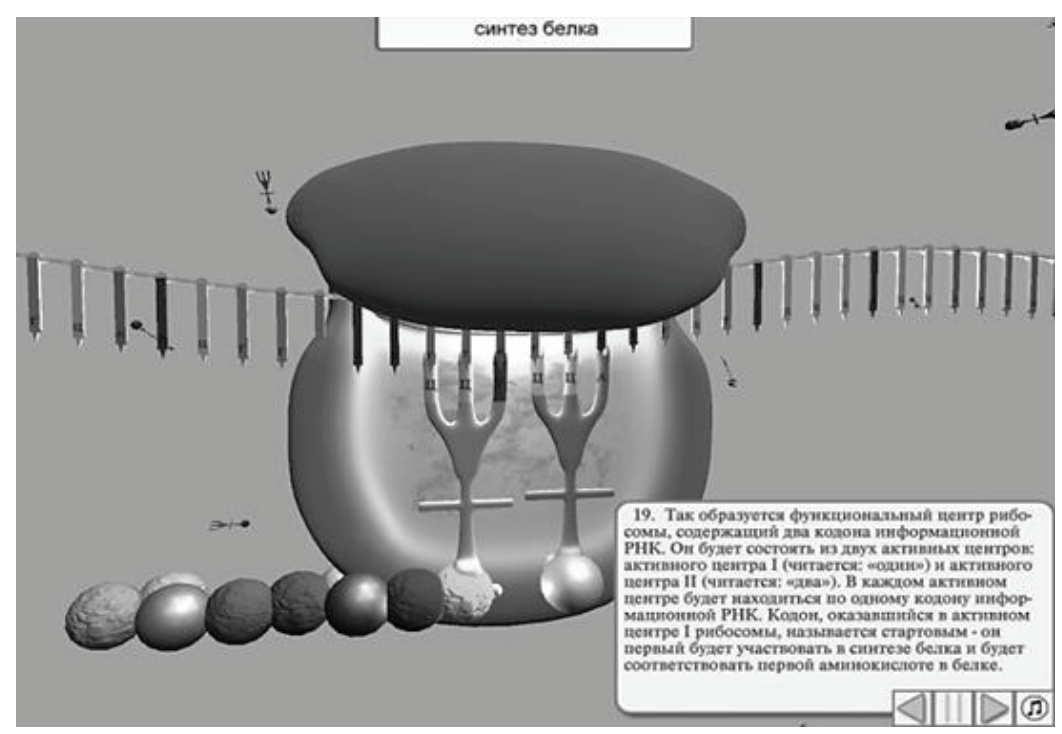

Figure 2. A screenshot from the program "Protein Synthesis" with animated ribosome mechanics, and audio and text explanation 
The following two psycho-therapeutic training programs were designed for adults under the authors' guidance: "Getting over nyctophobia" (fear of darkness), and "Getting over claustrophobia" (fear of confined spaces). Each program has a frame-by-frame scenario that can be edited according to the reliability of each particular case's ecological and educational requirements. All the elements are put together on the "Unity" platform; the final variant has a male avatar (Fig. 3).

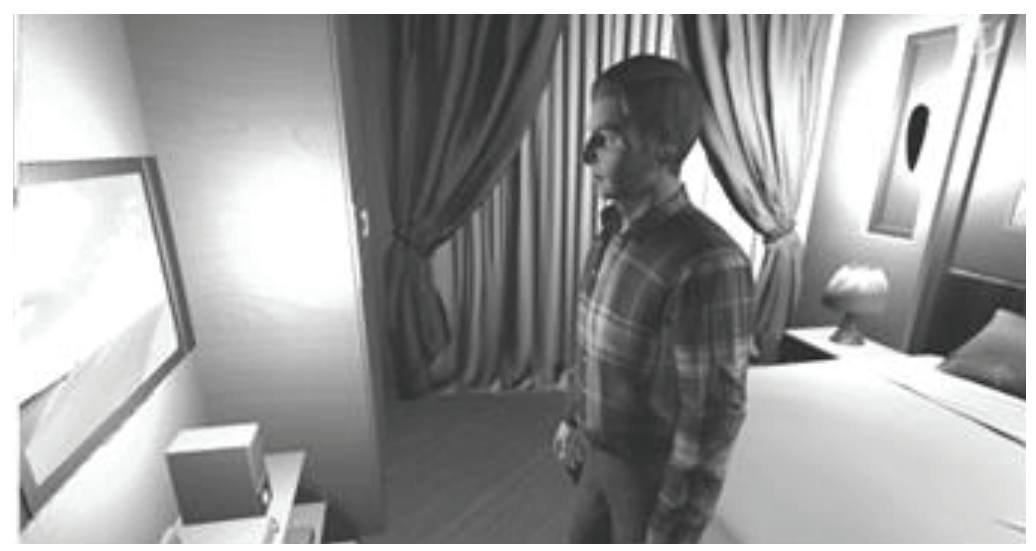

Figure 3. A screenshot from the program "Getting over nyctophobia". The subject under an avatar is placed in the room with a $5 \%$ shadow.

In the creation of VR-programs we used dynamic and static lighting, a particle system, dynamic cameras of various formats, and high-resolution textures. At first, most of the experiments were carried out with the help of ordinary $3 \mathrm{D}$ monitors, or with the VR Z800 3DVisor headset (eMagin), which displays with a resolution of $800 \times 600$ pixels; a field of view of $60 \times 40$ degrees was used for all cases.

As in most experimental series, a laboratory experiment (with a simple experimental plan for three independent variables) was used.

\section{Study Designs}

\section{The Impact of Educational VR Experience on the Retention of Auditory Material}

Subjects. The study included high school students in 10th grade (public high schools № 26 and 29, Smolensk, Russia), ages 16-18 (105 people); 46 were male, and 59 were female. They were divided into two groups: an experimental group of 50 students, and a control group of 55 students. The groups were equal in age and sex ratio.

Before viewing the educational VR program, the subjects were tested in Geometry and the following parameters were measured: the volume of short-term figurative, symbolic memory; the stability and shifting of attention; the ability to make generalizations; and field dependence/independence (cognitive style). After viewing the program, they were tested again with another test of a similar difficulty and their parameters were measured again. This stage also included diagnosing their thinking dynamics (changes in operations or intellectual actions) and processes (such as analysis, synthesis, and generalization). The dynamics of their cognitive activity were defined with the help of micro-semantic analysis of their reports. 
The experiment included a control group, which worked with a teacher on the same Geometry as in the VR program. The control group subjects were tested in the same way as the experimental group.

\section{The Impact of Educational VR Experience on Cognitive Processes}

Subjects. The experimental group included 25 adults, intellectually advanced (studying or having a university degree), ages 20-50, of which 12 were males and 13 females. The control group was comprised of 23 adults, 10 males and 13 females, all of whom specialized in subjects other than biology.

The test subjects were administered the classical psychological test on memorizing 12 images, 12 numbers, and numerical sequences before and after the viewing of the educational program in Biology "Protein synthesis."

Other cognitive processes were also analyzed during the study: changes in cognitive functions were studied with the help of the modified digital Shulte Table (switching of attention); the Bourdon-Anfimov proof test (the measurement of attention stability and concentration); exception of concepts and identification of the similarity to a concept (the ability to make generalizations and classifications; the test on finding general (common) concepts, including 20 sets of five words for finding the similarity to a concept; exclusion of concepts (17 sets of 5 words to exclude the odd one), etc.

Individual differences in cognition included the cognitive style characteristics of field dependence/independence (Witkin, et al., 1977; Witkin, et al., 1974) (EFT (Embedded Figures Test, H. Witkin).

\section{VR in Phobias Treatment}

Subjects. The study included young adults ages 21-55 (37 people), either in the university or with a university degree, who requested assistance at the Social and Psychological Center (Smolensk, Russia). The majority of them suffered from certain fears and phobias, or had suffered from phobias in the past, which they had overcome (19 people). The group consisted of 30 men (81\%) and 7 women (19\%), since the training programs were created with male avatars.

Each subject took a Spielberg-Khanin test several days before and after their VR experience to overcome a certain phobia. Their personal and reactive anxiety were then evaluated. The indices of self-evaluation of reactive and personal anxiety were treated as dependent variables, whereas parameters of the subjects' work with the VR-training programs were considered to be instructive independent variables.

The experiment included a control group treated in a conventional way.

\section{Ethical Statement}

All subjects gave their informed consent for inclusion before they participated in the study. The study was conducted in accordance with the Declaration of Helsinki of 1975, revised in 2013. All participants were over 18 years old and gave their written consent to take part in the experiments with VR-headsets. 


\section{Statistical Analysis}

Mann-Whitney and Kramer-Welch tests were used to find the differences between the experimental and control groups.

Statistical processing of the results was performed in STATISTICA 6.0, SPSS11v11.0.1 and included correlation analysis.

\section{Results}

\section{The Impact of Educational VR Experience on the Retention of Auditory Material}

The dependent variable was the actualization level of the students' knowledge in Mathematics (e.g., in solving mathematical problems); independent variables were the parameters of VR. At the beginning of the experiment, both groups were tested in Mathematics (10 problems test). Then one group of students was offered the opportunity to work with a VR educational program (in a computer lab), while the other group of students studied the topic with a teacher, without the use of any virtual program. After the class, both groups took Mathematics tests with two tasks, the content of which was related to the studied topic. The chosen topic was the application of the "Three perpendiculars theorem" of solid geometry. The results are summarized in Fig. 4.

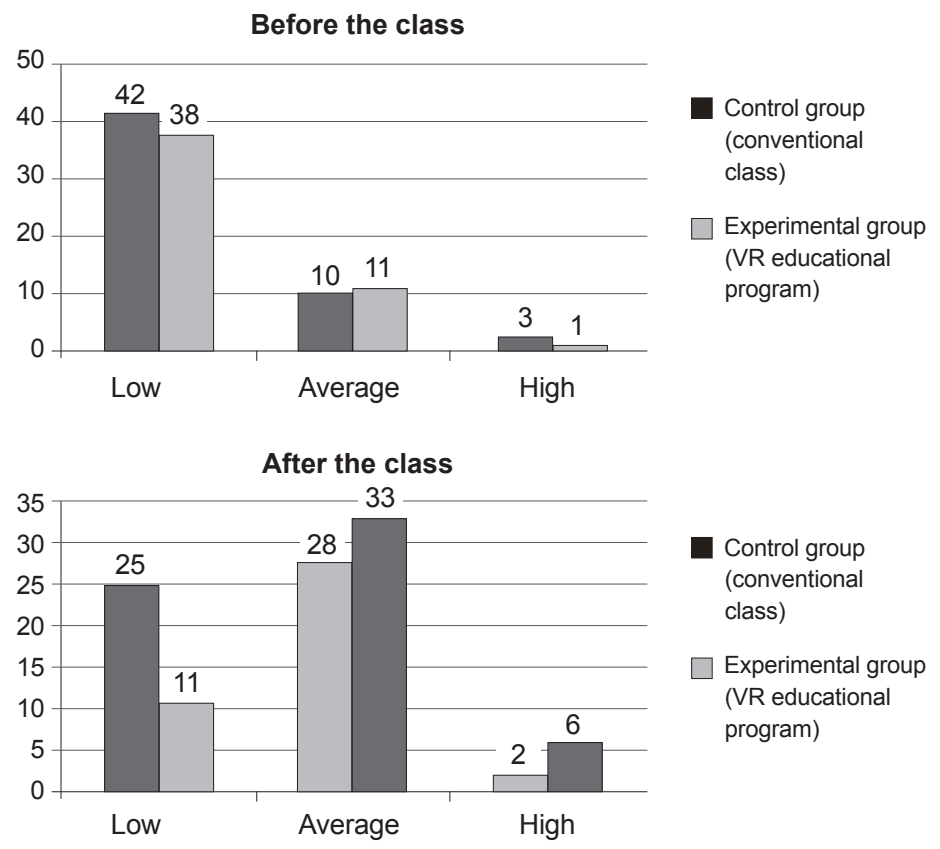

Figure 4. Test results in Mathematics (Geometry). Note. The histogram illustrates the results of the mathematics tests taken before and after the class with and without VR educational program

The application of the "Three perpendiculars theorem" VR-educational program in Geometry had the following results. According to P.A. Pobokin's data in a study carried out under our guidance, the parameters of the students' performance 
increased on average to 1.5 times the original score. The calculated empirical value of Student's $t$-criterion $(t=11.747)$ appeared to be larger than the critical Student's $\mathrm{t}$-criterion $(\mathrm{t}=2.05)$, which indicates the reliability of the improvement in the number of correct answers after the use of virtual mathematical program $(p=0.05)$. According to the homogeneity criterion $\chi 2$, three levels of knowledge development were distinguished: 1$) \mathrm{L}=3 ; 2) \mathrm{L}-1=2$; and therefore 3$) \times 2 \operatorname{cr}(2 ; 0.05)=5$.99. Since $\mathrm{x} 2 \mathrm{emp}=7.63>\times 2 \mathrm{cr}(2 ; 0.05)=5.99$, the reliability of differences in the test results between pupils using the virtual program and those having the teacher explain the topic, is $95 \%$ (significance level $\mathrm{p} \leq 0.05$ ).

The initial test results of both the experimental and control groups were the same (Student's T-test and Chi-square test, $\mathrm{p} \leq 0.05$ ). The final test results of the students after the use of the virtual program, and the test results of the students after the teacher explained the topic, were different, as measured by the Student's T-test $($ Temp $=11.74>$ Tcrit $=2.05)$; the Mann-Whitney test $($ Wemp $=3.025>$ Wcrit $=1.96)$; and the Kramer-Welch tests $($ Wemp $=3.22>$ Wcrit $=1.96), \mathrm{p} \leq 0.05)$. The average test score in the control group was 4.8, whereas the average results of those students who had worked with the VR program was 5.72. The application of the VR educational program in Geometry thus increased the parameters of the students' performance on average to 1.5 times the original score (from 3.78 to 5.72), while the control group's learning experience went up to 1.2 times (from 3.96 to 4.8). The size of the effect for the control sample is $d$ cont. $=0.60$; for the experimental, $-\mathrm{d}$ exp. $=1.29$ (Cohen's d, J. Cohen index).

Since all three statistical criteria (Mann-Whitney, Kramer-Welch, and chi uniformity) rejected the main hypothesis $(\mathrm{H} 0)$ at a significance level of $\mathrm{p} \leq 0.05$, and $\mathrm{d}$ (Cohen's d) is ex-large, it can be argued that empirical differences do exist. Therefore, the effect of changes in the results is caused by the use of a virtual program. The study subjects expanded the search zone of correct answers, and increased their semantic links.

It should also be noted that, after the application of the VR educational program, the number of students giving 6-8 correct answers out of 10 rose dramatically. There were also a small number of students who gave nine correct answers out of 10. Similar data were previously obtained with the use of VR programs in education (Pobokin, 2014; 2015 a, b).

\section{The Impact of Educational VR Experience on Cognitive Processes}

The test subjects in this experiment took a classical psychological test on the memorizing of images, numbers, and numerical sequences before the learning experience. After viewing the educational VR-program in Biology "Protein synthesis" (duration 11-20 min), the test subjects took the tests again. The adults in the control sample read a biology textbook for a secondary school on the topic "Protein Synthesis" for 20 minutes and were tested both before and after reading the material.

The VR educational programs had a considerable positive influence on the volume of short-term figurative memory (the difference of average indices was 1.96 in the experimental group, and 0.5 in the control group; the symbolic memory (memorizing numbers), and short-memory volume were less influenced (the 
differences of average indices were 0.08 and 0.28 . In the control group they were 0.04 and 0.09 ).

Other cognitive processes were also analyzed during the study: changes in cognitive functions were diagnosed with the help of the modified digital Shulte Table (switching of attention); the Bourdon-Anfimov proof test (the measurement of attention stability and concentration); the exception of concepts and identification of the similarities between concepts (study of generalizations), etc.

The VR educational program had a considerable influence on the powers of observation (in the differences detection test, the difference in average indices was 1.4 , as compared to 0.8 in the control group); attention stability and concentration (test Bourdon-Anfimov); and the ability to make generalizations and classifications (finding general (common) concepts, exclusion of concepts). The difference of average indices before and after the viewing of the VR program was 1.8; in the control group it was 1.1. The effect size for the control sample is $d$ cont $=0.30$; for the experimental, $\mathrm{d}$ exp. $=0.9$ (Cohen's d, J. Cohen index). Significant changes in all indicators have occurred after using the virtual program (the Wilcoxon criterion: Wemp $=26$, with Wcrit $=37$, Wemp $<$ Wcrit, $\mathrm{p} \leq 0.01$ ).

The decrease of parameters was only observed during the general switching of attention (modified digital Shulte Table): the average time of task solving increased from $136.4 \mathrm{sec}$. up to $158.2 \mathrm{sec}$., remaining at the average level of switching. Individual differences of cognition included the characteristics of cognitive style. VR programs caused a significant increase in field independence; the average time needed for solving tasks decreased from $42.3 \mathrm{sec}$. to $18.7 \mathrm{sec}$; in control group it went from $48.1 \mathrm{sec}$. to $40.02 \mathrm{sec}$.

Therefore, similar results were received after the application of the VR educational programs in both Geometry and Biology. Changes in the scores on Geometry (Biology) tests in the control sample, which used conventional education methods, were in the range of $10-15 \%$. The results show that the VR educational programs improved students' performance (for the students with a low performance the increases were $40-50 \%$; for high performers it was several times more than 100\%).

\section{The Impact of Training VR Experience in Treatment of Phobias}

Participants were introduced to a VR experience of a dark or confined place depending on their phobia. The interconnection between the virtual images and personality was analyzed with the help of MMPI both before and after the work in the VR. The subjects' anxiety levels (reactive and personal anxiety) were measured by the Spielberg-Khanin test (the State-Trait Anxiety Inventory) several days before and after the VR training program to overcome a certain phobia.

There were no significant alterations in the basic personal traits evaluated with the short MMPI version. The secondary diagnostics results of the personal characteristics also showed that no significant changes occurred. Thus the VR training programs did not have a significant influence on the basic personality traits (the Wilcoxon criterion: Wemp $=4$, with Wcrit $=1$, Wemp $>$ Wcrit, $\mathrm{p} \leq 0.01$ ).

The alteration of the anxiety level was based on average values. During the primary diagnostics, the subjects had the average of reactive anxiety of 54.3 and personal anxiety of 56. During the secondary diagnostics, the reactive anxiety was 36 and personal anxiety was 52. Consequently, significant changes occurred (the 
Wilcoxon criterion Wemp $=11$, with Wcrit $=27$, Wemp $<$ Wcrit, $\mathrm{p} \leq 0.01$ ) for the experimental sample, while no significant changes were observed in the control sample (the Wilcoxon criterion: Wemp $=17$, with Wcrit $=3$, Wemp $>$ Wcrit, $\mathrm{p} \leq 0.01$ ). The effect size for the control sample is $\mathrm{d}$ cont. $=0.2$; for experimental, $\mathrm{d}$ exp. $=0.98$ (Cohen's d, J. Cohen index).

The VR activity performed under an avatar and targeted at overcoming fears dramatically decreased the subjects' reactive anxiety, while there was practically no alteration of personal anxiety. Reactive anxiety is considered to be a situational, functional, and personal characteristic, which reflects general overstrain, worrying, and nervousness. Personal anxiety is connected with more stable characteristics, which make a person perceive a wider circle of situations as threatening, which results in turn in the manifestation of anxiety. It is probable that the short-term immersion into the VR environment primarily affected the degree of reactive anxiety, lowering its indices from high to moderate values. However, not all the subjects had such low indices; the average value decreased by 1.5 (for more, see Selivanov, V.V. (Ed.), 2016).

Our results correlate with the data gathered in the United States and Israel on the decrease of different kinds of anxiety after a short-term application of virtual programs, which helped to overcome the fear of public speaking (Harris et al., 2002; Wallach et al., 2006).

\section{Discussion}

There is little question but that VR educational programs have some influence on a person. At the same time this situation is rather problematic since the possibility of their further application depends directly on the degree of influence the VR exerts on cognitive processes and personality properties. Nowadays there are some publications which support the use of VR technologies for educational purposes, without proper discussion of their effect.

VR training programs are treated with some suspicion because they are often associated with some special world which withdraws the person from the present reality, causes virtual dependence, etc. Among the negative effects which accompany VR are the presence effect (McLellan, 1996; Lombard, \& Ditton., 1997); the Proteus effect (Yee et al., 2009); virtual ego-dissolution (Metzinger, 2018); the immersion effect, etc. These effects result from constant surfing the virtual worlds, where a user can spend more than 20 hours per week using avatars. Modern Internet and computer games content already contains elements of VR, in particular, an immersive environment with avatars (including games like Call of Duty, World of Warcraft, League of Legends, etc.). The problem of minimizing the high-risk internet behaviors, which in adolescence are associated with styles of parental control like supervision (condoning) (Álvarez-García et al., 2018), is posed. The present study has been devoted to VR educational functions when they are used for a short period of time without any avatars in the educational programs (the avatar was used in the training program).

Why does education organized with the adequate use of VR turn out to be such effective educational environment? Probably, as the research shows, it is because 
the VR performs three main functions: it can be a method, means and technology of education (Selivanov, \& Selivanova, 2014). Apart from this, VR has three basic mechanisms which stimulate the development of cognitive processes.

The first mechanism is connected with a percept (super-image) created in the virtual environment: its holographic, distinct character constructs personal mental images in perception and memory, as well as a figurative plan for thinking (necessary for symbolic modeling).

The second mechanism is based on the VR animation opportunities (performing a wide range of actions with virtual objects). It thus stimulates the intensive development of a perception plan, memory, and thinking (it is combined with the structural plan). Some studies emphasize the importance of hand gestures for virtual education (in modern VR-education content where the hand is a VR-controller) (Johnson-Glenberg, 2018).

The third mechanism is based on the presence effect in VR, which encourages the development of specific cognitive motivation of a person, and creates the motivational plan of perception, memory, and thinking. These basic mechanisms are key elements of training programs.

\section{Conclusion}

Short-term work in educational VR positively affects the development of knowledge, thinking, and other cognitive processes. VR educational programs stimulate personal, procedural, and operational mechanisms of thinking, which result in the higher student performance. VR-programs improve traditional parameters of figurative short-term memory, observation, stability and attention span, and generalization and classification; they also increase field independence (cognitive style). The educational virtual environment causes a decrease in traditional switching of attention parameters.

However, the use of the VR educational programs may also cause some negative effects, such as a "super-figurative," visual presentation of educational information that can reduce the development of abstract concepts and symbolic thinking.

The work with training and educational programs in VR does not affect a person's basic personality characteristics (the indices on the main MMPI scales). At the same time the application of VR training programs designed to trigger personal alterations have a great influence on the modification of the functional personal properties, such as reactive anxiety.

\section{Limitations}

The present investigations are aimed at identifying the most common laws of influence of short-term programs in VR on cognitive processes and personal characteristics. Young, mentally healthy people involved in learning participated in the experiments. In the future, it may be possible to obtain slightly different data by expanding the sample and increasing the time spent in VR.

Author Contributions. Conceptualization, Methodology, Writing - Original Draft Preparation, Experiments, Funding Acquisition, V.S.; Writing - Review \& 
Editing, Data Curation, Supervision, L.S., N.B.; Didactic Correction of Scenarios of VR-programs, L.S.; Conducting experiments, L.S., N.B.; Ecological Verification of Program Scenarios, N.B.

\section{Acknowledgements}

The present research is an assignment of the RF Ministry of Science and Higher Education for 2020-2023.

The authors thank software developer V.P. Titov for the creation of the educational and training software products in VR; the associate professor P.A. Pobokin for the scenarios of VR programs in Geometry; and the teacher P.V. Sorochinsky for the scenarios of VR-programs in Biology.

\section{References}

Álvarez-García, D., García, T., \& Suárez-García, Z. (2018). The Relationship between Parental Control and High-Risk Internet Behaviours in Adolescence. Social Science, 7(6), 87. https://doi.org/10.3390/socsci7060087

Byrd Christy, M. (2018). Microaggressions Self-Defense: A Role-Playing Workshop for Responding to Microaggressions. Social Science, 7(6), 96. https://doi.org/10.3390/socsci7060096

Faria, A.L., Cameirao, M.S., Couras, J.F., Aguiar, J.R., Costa, Ga.M., \& Bermudez i Badia, S. (2018). Combined Cognitive-Motor Rehabilitation in Virtual Reality Improves MotorOutcomesin Chronic Stroke - A Pilot Study. Frontiers in Psychology, 9. https://doi.org/10.3389/fpsyg.2018.00854

Harris, S.R., Kemmerling, R.L., \& North, M.M. (2002). Brief Virtual Reality Therapy for Public Speaking Anxiety. Cyber Psychology \& Behavior, 5(6), 543-550. https://doi.org/10.1089/109493102321018187

Hodges, L.F. Anderson, P., Burdea, G.C., Hoffman, H.G., \& Rothbaum, B.O. (2001). Treating Psychological and Physical Disorders with VR. IEEE Computer Graphics and Applications, 21(6), 25-33. https://doi.org/10.1109/38.963458

Huan, X. (2017). Measuring the Efficiency of Education and Technology via DEA approach: Implications on National Development. Social Science, 6(4), 136. https://doi.org/10.3390/socsci6040136

Johnson-Glenberg, M.C. (2018). Immersive VR and Education: Embodied Design Principles That Include Gesture and Hand Controls. Frontiers in Psychology, Front. Robot. https://doi.org/10.3389/frobt.2018.00081

Lombard, M., \& Ditton, T. (1997). At the heart of it all: The concept of presence. Journal of ComputerMediated Communication, 3(2), 1-33. https://doi.org/10.1111/j.1083-6101.1997.tb00072.x

McLellan, H. (1996). Virtual realities. In D.H, Jonassen (Ed.), Handbook of research for educational communications and technology (pp. 457-487). N.Y.: Macmillan.

Menshikova, G.Ya. (2013a). Zritel'nye illiuzii: psikhologicheskie mekhanizmy i modeli [Visual illusions: psychological mechanisms and models] (Doctoral dissertation). Moscow: Lomonosov State University.

Menshikova, G.Ya. (2013b). An investigation of 3D images of the simultaneous-lightness-contrast illusion using a virtual-reality technique. Psychology in Russia: State of the Art. 6(3), 49-59. https://doi.org/10.11621/pir.2013.0305

Menshikova, G.Ya., Kovalev, A.I., Klimova, O.A., \& Barabanschikova, V.V. (2017). The application of virtual reality technology to testing resistance to motion sickness. Psychology in Russia: State of the Art, 10(3), 151-163. https://doi.org/10.11621/pir.2017.0310

Menshikova, G.Ya., Saveleva, O.A., \& Zinchenko, Y.P. (2018). The study of ethnic attitudes during interactions with avatars in virtual environments. Psychology in Russia: State of the Art, 11(1), 20-31. https://doi.org/10.11621/pir.2018.0102 
Metzinger, T.K. (2018). Why is Virtual Reality interesting for Philosophers? Frontiers in Psychology, Front. Robot. https://doi.org/10.3389/frobt.2018.00101

Meyerbroeker, K., \& Emmelkamp, P.M.G. (2008). Therapeutic processes in virtual reality exposure therapy: The role of cognition and the therapeutic alliance. CyberTherapy \& Rehabilitation, 1(3), 247-257.

Murray, K. (2000). Internet-zavisimost's tochkami zreniia narrativnoi psikhologii [Internet addiction from the perspective of narrative psychology]. In A.E. Voyskunsky (Ed.), Gumanitarnyie issledovaniya $v$ Internete [Humanitarian research on the Internet] (pp. 132-140). Moscow: MozhayskTerra.

Norris, J., \& Saudelli, M.G. (2018). Heating Up Online Learning: Insights from a Collaboration Employing Arts-Based Research/Pedagogy for an Adult Education, Online, Community Outreach Undergraduate Course. Social Science, 7(7), 104. https://doi.org/10.3390/socsci7070104

Pobokin, P.A. (2015a). Vliianie sredstv virtual'noi real'nosti na razvitie myshleniia $i$ znanii shkol'nikov po matematike $v$ puti obucheniia [The influence of the means of virtual reality on the development of thinking and knowledge of pupils in mathematics during schooling] (PhD thesis). Smolensk.

Pobokin, P.A. (2015b). Izmenenie refleksivnosti shkol'nikov na urokakh matematiki kak rezul'tat primeneniia virtual'nykh obuchaiushchikh programm [The change in the reflexivity of pupils at mathematics lessons as a result of the use of virtual training programs]. In V.V.Selivanov (Ed.), Psihologiya kognitivnyih protsessov (pp. 149-154). Smolensk: Izdatelstvo SmolGU.

Pobokin, P.A. (2014). Razvitie myslitel'nykh protsessov shkol'nikov, ikh psikhicheskikh sostoianii kak sledstvie primeneniia virtual'nykh matematicheskikh programm [Development of students' thinking processes: their mental conditions as a result of the virtual mathematical programs application]. Vestnik Cherepovetskogo gosudarstvennogo universiteta, 3(56), 192-197.

Riva, G. (2001). Virtual Reality in Psychotherapy: Review. CyberPsychology \& Behavior, 8(3), 220-230. https://doi.org/10.1089/cpb.2005.8.220

Riva, J. (2008). Virtual reality in health care: An introduction. CyberTherapy \& Rehabilitation. 1, 6-9. https://doi.org/10.1037/e548252010-001

Rothbaum, B.O., \& Hodges, L.F. (1990). The Use of Virtual Reality Exposure in the Treatment of Anxiety Disorders. Behavior Modification, 23(4), 507-525. https://doi.org/10.1177/0145445599234001

Seliskya, M.A., Voiskynsky, A.E., Ignatev, M.B., \& Nikitin, A.V. (2004). Primenenie virtual'noi real'nosti v kachestve psikhoterapevticheskogo sredstva dlia pomoshchi stradaiushchim ot psikhologicheskikh fobii [Virtual reality as a psychotherapeutic method of treating phobias]. In Trudy VII Vserossiiskoi ob"edinennoi konferentsii 'Tekhnologii informatsionnogo obshchestva - Internet $i$ sovremennoe obshchestvo' [Proceedings of the All-Russian Research Institute of the All-Russian Joint Conference "Technologies of the Information Society - Internet and Modern Society]" (pp. 39-42). SPb.: Izd-vo Filologicheskogo fakulteta SPbGU.

Selivanov, V.V. (Ed.) (2015). Psikhologiia virtual'noi real'nosti (uchebnoe posobie) [Psychology of virtual reality (tutorial)]. Smolensk: Izdatelstvo SmolGU.

Selivanov, V.V. (Ed.) (2016). Sub"ekt i virtual'naia real'nost': psikhicheskoe razvitie, obuchenie [Subject and virtual reality: mental development, training]. Smolensk: Izdatelstvo SmolGU.

Selivanov, V.V., \& Selivanova, L.N. (2014). Virtual'naia real'nost' kak metod i sredstvo obucheniia [The virtual reality as a method and means of training]. Obrazovatel'nye tekhnologii i obshchestvo [Educational Technology \& Society], 17(3), 378-391. Retrieved from http://ifets.ieee.org/russian/periodical/journal.html

Slater, M., \& Sanchez-Vives, M.V. (2016). Enhancing our lives with Immersive virtual reality. Frontiers in Psychology, Front. Robot. https://doi.org/10.3389/frobt.2016.00074

Yee, N., Bailenson, J.N., \& Ducheneaut, N. (2009). The Proteus Effect: Implications of transformed digital self-representation on online and offline behavior. Communication Research, 36(2), 285-312. https://doi.org/10.1177/0093650208330254

Velichkovsky, B.B., Gusev, A.N., Vinogradova, V.F., \& Arbekova, O.A. (2016). Kognitivnyi kontrol' i chuvstvo prisutstviia v virtual'nykh sredakh [Cognitive control and sense of presence in virtual environments]. Eksperimentalnaya psihologiya, 9(1), 5-20. https://doi.org/10.17759/exppsy.2016090102 
Voiskynsky, A.E. (2010). Psikhologiia i internet [Psychology and the Internet]. Moscow: Akropol. Wallach, H.S., Bar-Zvi, M., \& Safir, M. (2006). Virtual Reality-Assisted Treatment of Public Speaking Anxiety. CyberPsychology \& Behavior, 9(6), 725-726. https://doi.org/10.1037/e695432011-143

Witkin, H.A., \& Goodenough, D.R. (1977). Field Dependence and Interpersonal Behavior. Psychological Bulletin, 84, 661-689. https://doi.org/10.1037/0033-2909.84.4.661

Witkin, H.A. (Ed.) (1974). Psychological Differentiation. Studies of Development. N.Y.: Wiley.

Zinchenko, Y.P., Kovalev, A.I., Menshikova, G.Ya., \& Shaigerova, L.A. (2015). Postnonclassical methodology and application of virtual reality technologies in social research. Psychology in Russia: State of the Art, 8(4), 60-71. https://doi.org/10.11621/pir.2015.0405

Original manuscript received April 23, 2019 Revised manuscript accepted January 20, 2020

First published online June 15, 2020

To cite this article: Selivanov, V.V., Selivanova, L.N., Babieva, N.S. Cognitive Processes and Personality Traits in Virtual Reality Educational and Training. Psychology in Russia: State of the Art, 13(2), 16-28. DOI: 10.11621/pir.2020.0202 